\title{
Differences in herbivore feeding preferences across a vertical rocky intertidal gradient
}

\author{
Carol S. Thornber ${ }^{1, *}$, Emily Jones ${ }^{1,2}$, John J. Stachowicz ${ }^{3}$ \\ ${ }^{1}$ Dept. of Biological Sciences, University of Rhode Island, 100 Flagg Rd, Kingston, Rhode Island 02881, USA \\ ${ }^{2}$ Bodega Marine Laboratory, University of California, Davis, Bodega Bay, California 94923, USA \\ ${ }^{3}$ Section of Evolution and Ecology, University of California, Davis, 1 Shields Ave, Davis, California 95616, USA
}

\begin{abstract}
Primary producers such as plants and macroalgae can vary in palatability to their herbivorous grazers; this leads to variation in the intensity of herbivory, which can play an important role in setting the composition and diversity of producer assemblages. However, despite strong gradients in the composition and abundance of herbivores across intertidal gradients, little is known about how macroalgal palatability and associated herbivore defenses vary across strong vertical gradients in marine rocky intertidal zones. Plant defense theory predicts that decreasing intensity of herbivory with increasing tidal elevation should result in higher intertidal species being more palatable and less defended than their lower intertidal counterparts. In this study, we examined the relative palatability of 9 pairs of closely related macroalgal species that occupy different elevations across this vertical gradient, to 3 of the most common local herbivores. We conducted controlled paired-choice feeding assays for every herbivore-algal species combination. Although we found no evidence for a vertical gradient in palatability consistent across all 3 herbivores, there were many significant, species-specific herbivore preferences driven by morphological and/or chemical properties of the macroalgae. In general, herbivores consumed more of the algae that they did not co-occur with: the lower intertidal herbivores Strongylocentrotus purpuratus and Tegula brunnea preferred higher intertidal algae overall, and the higher intertidal herbivore Tegula funebralis preferred lower intertidal algae. Our results suggest that the intensity of herbivory may change with tidal elevation in more complex ways than previously suspected, and that studies of macroalgal palatability and antiherbivore defenses in these systems will need to examine the relative impacts of a range of herbivores on algal community structure.
\end{abstract}

KEY WORDS: Herbivore preference $\cdot$ Rhodophyta $\cdot$ Phaeophyceae $\cdot$ Grazer $\cdot$ Elevational gradient

\section{INTRODUCTION}

Geographic gradients in both primary producer palatability and herbivore intensity have been well documented in both marine and terrestrial systems; see reviews by Levin (1976) and Gaines \& Lubchenco (1982), and more recent studies, including Alonso (1999), Scheidel et al. (2003), and Long \& Trussell (2007). Tropical marine systems are typically characterized by very high levels of herbivory (Carpenter 1986, Hay \& Steinberg 1992, Floeter et al. 2005) and tropical marine algae are often heavily defended by morphological and/or chemical characteristics (Hay et al. 1988, Meyer \& Paul 1995, Granado \& Caballero
2001). When compared to their closely related temperate counterparts, tropical algal species may have higher levels of chemical defenses and be less palatable (Bolser \& Hay 1996). A similar latitudinal gradient in the strength of herbivory and plant defenses has been documented for salt marsh plants along the Atlantic coastline of the USA (Pennings \& Silliman 2005) and in Europe (Pennings et al. 2007).

Gradients in palatability and herbivory may also vary on vertical (elevational) scales. In terrestrial systems, plant palatability increases along an increasing elevational gradient; correlated with this is a decrease in the intensity of herbivory (Bruelheide \& Scheidel 1999, Salmore \& Hunter 2001). Intertidal systems, with 
their compact stress gradient, have often been assumed to be experimentally tractable analogs of larger biogeographic or altitudinal gradients. However, little is known about vertical gradients of herbivory and macroalgal palatability in marine systems, and to our knowledge no studies have explicitly tested whether intertidal algae exhibit gradients in palatability or defenses among species analogous to those reported on biogeographic scales.

In rocky intertidal systems, for example, a gradient of increasing plant palatability with increasing elevation could occur if (1) there is a vertical gradient in herbivore pressure and (2) a trade off between growth, stress tolerance, and defense (e.g. as hypothesized by Rhoades 1979). First, the number, diversity, and composition of herbivores (Wolcott 1973, Morris et al. 1980, Paine et al. 1985, Scheibling 1994, Chavanich \& Wilson 2000), as well as the intensity of consumption (Menge \& Sutherland 1976, 1987), are well known to change with tidal elevation due to a combination of factors. Chiefly, this gradient occurs because most intertidal grazers are marine and fewer kinds of animals are able to survive the longer the duration of emersion at high tidal elevations. Even among grazer species that can survive extended emersion, the time each individual can spend feeding will generally decline with increasing elevation. Few terrestrial animals are significant macroalgal grazers in California intertidal systems.

This gradient in the intensity of consumption could produce a gradient in the palatability of algae through a combination of 2 mechanisms. First, only species with low palatability should persist in the low intertidal, where herbivory is intense. Second, higher intertidal macroalgae are exposed to wider daily fluctuations in temperature and salinity than their lower intertidal counterparts and thus are subject to greater environmental stress (Connell 1961, Paine \& Vadas 1969, Menge 1991). If hypothesized tradeoffs between defense and stress tolerance exist, higher intertidal species (or individuals) may allocate more resources toward surviving these abiotic stresses and hence have fewer resources to devote to herbivore defense. This has been demonstrated within at least 1 species: palatability of the brown alga Fucus vesiculosus decreases with tidal elevation; controlled field experiments demonstrated this to be the result of increased environmental stress in the high intertidal (Deal 1997), suggesting that the defense vs. stress tolerance tradeoff may be real in intertidal algae.

In this study we assess whether gradients in the intensity of herbivory and tradeoffs between defense and other life functions are sufficiently strong to produce a vertical gradient in relative macroalgal palatability. We examined this question through a series of laboratory-based paired-choice feeding preference assays. We used common macroalgal species and invertebrate herbivores from a rocky intertidal system along the west coast of the USA. Specifically, we asked 2 questions: (1) Is there a vertical gradient in macroalgal palatability when comparing herbivore preference between phylogenetically or functionally similar species? (2) Can palatability differences among high and low intertidal species pairs be explained by differences in morphology, chemistry, tissue toughness and/or nutritive content?

\section{MATERIALS AND METHODS}

Study system. We selected every possible pair $(n=9)$ of macroalgal species from around Bodega Bay, California, USA, in which each pair contained closely related species (confamilial or congeneric in most cases) with similar morphologies, but occupying different tidal height levels on rocky shores. For all pairs, at least 1 member of the pair had been observed to be consumed by common intertidal herbivores in the field. The tidal levels range from high intertidal to shallow subtidal (a difference of approximately $3 \mathrm{~m}$ ) and we recorded the tidal height range of each species using survey equipment (C. Thornber unpubl. data). The 9 species pairs selected, with the higher intertidal species listed first, were: (1) the kelps Saccharina sessile (C. Agardh) Kuntze (previously Hedophyllum sessile; Lane et al. 2006) and Laminaria setchellii P.C. Silva, in the family Laminariaceae; (2) the kelps Postelsia palmaeformis Ruprecht and Nereocystis luetkeana (Mertens) Postels \& Ruprecht, in the family Laminariaceae; (3) the fucoids Pelvetiopsis limitata (Setchell) N.L. Gardner and Cystoseira osmundacea (Turner) C. Agardh in the order Fucales; (4) the fucoids Pelvetiopsis limitata and Fucus distichus subsp. evanescens (C. Agardh) Powell in the family Fucaceae; (5) the coralline algae Corallina vancouveriensis Yendo and Bossiella orbigniana (Decasine) P.C. Silva in the family Corallinaceae; (6) the foliose red algae Mastocarpus papillatus (C. Agardh) Kützing and Chondracanthus exasperatus (Harvey \& Bailey) J.R. Hughey in the order Gigartinales; (7) the foliose red algae Mazzaella flaccida (Setchell \& N.L. Gardner) Fredericq and Mazzaella splendens (Setchell \& N.L. Gardner) Fredericq; (8) the highly branched red algae Microcladia borealis Ruprecht and Microcladia coulteri Harvey; and (9) the foliose red algae Mazzaella flaccida (high) and Mazzaella flaccida (low). All species will be subsequently referred to by their genus name alone, except for congeners. Previous studies have documented the abundance and distribution of most of these species (Abbott \& Hollenberg 1976, Sousa et al. 1981, Foster 1982, Murray 1989, Murray \& Horn 1989, Schiel et al. 2004). 
In all cases except for Mazzaella flaccida, the vertical range of each species was too narrow ( $30 \mathrm{~cm}$ or less) to allow for any valid intraspecific comparisons of algal palatability across tidal heights. While ideally we might have compared high versus low intertidal congeners for all comparisons, it was simply not the case that valid congeners always occur split between high and low intertidal locations. Also, to avoid confounding factors in palatability, such as the presence of reproductive structures or tissues (Thornber et al. 2006), we used nonreproductive tissues for all assays.

We selected 3 of the most abundant herbivores in this systems: the low intertidal/subtidal purple sea urchin Strongylocentrotus purpuratus Stimpson, the low intertidal/subtidal turban snail Tegula brunnea Philippi, and the higher intertidal turban snail Tegula funebralis A. Adams for our feeding assays (Foster et al. 2003, Thornber et al. 2006, Snellen et al. 2007); these Tegula species were very recently reclassified as Chlorostoma species (Carlton 2007). These herbivores previously had been observed consuming at least 1 species of each algal species pair in the field (Steinberg 1985, C. Thornber pers. obs.). Other common large herbivores in this system include the kelp crab Pugettia producta Randall and the prickleback fish Xiphister mucosus Girard (Hines 1982, Horn et al. 1982, Byrnes et al. 2006). We conducted feeding assays with these 2 species as well, but both consumed little, if any, of our experimental algae (instead preferring Macrocystis spp. and Ulva spp., respectively, C. Thornber pers. obs.).

Whole-tissue assays. To determine if herbivores discriminate between higher and lower intertidal macroalgae, we performed paired-choice feeding preference assays on living macroalgal tissues of each of the 9 species pairs with each of the 3 herbivore species (with 1 exception, noted below). Macroalgae were collected in the field and their wet mass was measured after spinning each piece 15 to 20 times in a salad spinner to remove excess water. Initial wet masses ranged between 0.75 and $2 \mathrm{~g}$, corresponding to roughly 6 to $9 \mathrm{~cm}^{2}$ of surface area. To assess herbivore selectivity, we calculated the mass consumed (initial minus final wet mass) of each tissue sample. Two pieces of tissue (one from each algal species in a pair) were placed in a container in a flow-through seawater system with 1 herbivore, for a total of 20 replicates per experiment. Containers were 2 and 51 plastic paint-mixing buckets for snail and urchin assays, respectively. We used an equal number of non-herbivore controls for each assay; the changes in mass for control tissue did not differ significantly from zero and thus are not discussed further here. Each replicate was terminated when approximately one-third to one-half of the total tissue biomass had been consumed. We disregarded replicates from which (1) herbivores did not consume any tissue after
$3 \mathrm{~d}$, or (2) both pieces were completely consumed in less than $12 \mathrm{~h}$ (which was rare). Prior to each experiment, all herbivores were starved for 2 to $3 \mathrm{~d}$ to standardize hunger levels; non-starved herbivores frequently consumed little algal tissue within the first $3 \mathrm{~d}$ of an experiment, while most algal tissue began to degrade after (but not before) approximately $3 \mathrm{~d}$ in the seawater system. Overall, 25 feeding assays were conducted. The Corallina/Bossiella species pair was only tested against the purple urchin; both of these species are very tough coralline algae, and neither species of turban snail grazed on either tissue in preliminary experiments (C. Thornber pers. obs.).

Freeze-dried assays. For all algal species pairs in which herbivores demonstrated a significant difference in consumption between living macroalgal tissues, we tested whether physical (structural) differences between the species explained herbivore selectivity. We freeze-dried and then ground each macroalgal species into a fine powder in a Wiley Mill, mesh size 60 (GE Motors). We then reconstituted each species into squares of artificial food at natural wet-dry mass ratios by adding heated deionised water-agar mixture (Bacto $^{\mathrm{TM}}$ Agar, Becton, Dickinson, and Company) to the dry algal powder dissolved in water; the exact proportions varied based on the percent water composition of each algal species. This slurry was then poured onto window screening, upon which it cooled and adhered, for urchin feeding trials (Bolser \& Hay 1996). One piece of window screening containing a block of each of the 2 artificial food types $\left(\sim 3 \mathrm{~cm}^{2}\right.$ each) was given to each herbivore $(n=20)$. The area (no. of squares) of reconstituted food of each type eaten was recorded.

Because Tegula brunnea and T. funebralis feed via radular scraping, we poured a very thin layer of the slurry onto filter paper for snail feeding trials $\left(\sim 6 \mathrm{~cm}^{2}\right.$ of food). A digital photograph of each piece of artificial food was taken both pre and post exposure to T. funebralis and T. brunnea; each snail was given a choice of 2 artificial food types corresponding to the 2 macroalgal species (20 replicates, as in the urchin feeding trials). We analyzed the area of algae eaten via image analysis (ImageJ, www.nih.gov). All feeding trials lasted from 1 to $3 \mathrm{~d}$, and the experimental design was the same as for the whole-tissue feeding assays (above). Eleven different freeze-dried assay experiments were conducted.

Chemical extract assays. For species pairs in which there was a significant feeding preference in the freeze-dried tissue assays, we assessed the effects of chemical extracts from the algae on herbivore consumption. From wet tissue of each algal species, we extracted the crude lipophilic and water-soluble chemical fractions (see Hay et al. 1994, Thornber et al. 2006). 
We ground a known tissue volume in a blender, then extracted the tissue twice with a 2:1 ratio of dichloromethane:methanol for the lipid-soluble fraction, and then subsequently extracted with a 1:1 ratio of water:methanol for the water-soluble fraction. For each extraction step, we used at least twice as much methanol (by volume) as the original algal tissue's volume. Solids were removed by filtration. The crude extract was partitioned to separate the water and lipid soluble fractions and the solvents were removed via rotary evaporation. We then coated the chemical extracts onto freeze-dried, ground tissue of the kelp Macrocystis spp. (see Thornber et al. 2006 for methods), which is a known palatable food for these 3 herbivores (Byrnes et al. 2006).

The mixture of chemical extracts on Macrocystis was prepared into artificial food, as described in the 'Freeze-dried assays' subsection. The chemicals in the extracts were present in the same volumetric concentrations as would be found in living tissue for each species. The palatability of water soluble and lipid soluble fractions were tested separately. Extracts coated onto artificial foods were tested in the same pairs as the whole-tissue and freeze dried material, to test whether chemical extracts were responsible for initial differences in whole-tissue feeding preferences.

Statistical analyses of feeding assays. To avoid pseudoreplication, individual herbivores were used for only 1 feeding assay. We analyzed all paired-choice feeding assays (whole-tissue, freeze-dried, and chemical extract assays) with nested ANOVAs (JMP v5.1 www.sas.com). Algal origin (high/low intertidal) was nested within algal pairs, and Tukey's HSD was then used to examine differences within individual pairs.

Tissue characteristics. We also measured the tissue toughness and percent organic content of macroalgal tissues to assess whether these factors could help explain any observed differences in herbivore selectivity. We constructed a tissue penetrometer (Duffy \& Hay 1991) and used 5 blades from each species to assess the force required to penetrate the thallus. Ten locations were randomly selected on each blade and tested; the results (ml $\mathrm{H}_{2} \mathrm{O}$ needed to pierce the thallus) of these 10 trials per blade were averaged prior to statistical analysis. The toughness of the coralline algal pair Corallina and Bossiella exceeded our measurement capabilities; both are extremely tough due to calcification in their thalli.

As a proxy for nutritive content, we determined the percent organic content (as ash-free dry mass) of each species by combusting 10 dried blades of each species in a muffle furnace for $2 \mathrm{~h}$ at $500^{\circ} \mathrm{C}$. We analyzed all tissue data with nested ANOVAs (JMP v5.1, www.sas. com). Algal origin (high/low intertidal) was nested within algal pairs, and Tukey's HSD was then used to examine differences within individual pairs.

\section{RESULTS}

\section{Strongylocentrotus purpuratus feeding preferences}

Overall, the low intertidal urchin Strongylocentrotus purpuratus consumed 1.5 times more tissue from the higher intertidal algal species, with significant differences among species pairs (Fig. 1A, Table 1, p $<0.0001$ for both tidal height and species pairs). Planned multiple comparisons revealed that there were significant differences in 6 of the 9 species pairings. Urchins consumed 3 to 4 times as much tissue of each higher algal species than its lower counterpart in 4 cases (Corallina/ Bossiella, Mastocarpus/Chondracanthus, Mazzaella flaccida/ splendens, and Postelsia/Nereocystis; $\mathrm{p}<0.05$ for all). In contrast, for 2 species pairs, urchins consumed more tissue from lower intertidal species (Saccharina/Laminaria and Microcladia borealis/coulteri, $\mathrm{p}<0.05$ for both).

When we ran feeding assays on tissues that were homogenized to remove natural morphological differences among species, the significant difference in urchin consumption of high and low intertidal algal tissue remained $(p<0.0001)$, although there were not significant differences among algal pairs ( $p=0.7845$, Fig. 2, Table 1). Multiple planned comparisons revealed that 4 of the 6 significant feeding preferences in the whole-tissue trials remained intact when tissue was homogenized; only urchin preferences among both pairs of kelps (Saccharina/Laminaria and Postelsia/Nereocystis) disappeared as a result of homogenization. The 4 significant preferences that remained included 3 pairs in which the higher intertidal species was preferred (Corallina, Mastocarpus and Mazzaella flaccida) and 1 pair in which the lower intertidal species was preferred (Microcladia coulteri, Fig. 2A). These preferences were not reflected in urchin consumption of artificial foods laced with chemical extracts from any of these pairs (Fig. 3, Table 1, p = 0.2111 ), although there was a trend in the water-soluble extracts for increased consumption of both the higher Corallina and Mazzaella flaccida and the lower Microcladia borealis that matched the whole-tissue and freeze-dried assays (Fig. 3).

\section{Tegula brunnea feeding preferences}

The low intertidal snail Tegula brunnea exhibited significant preferences among species pairs and for high intertidal tissue over low intertidal tissue (Fig. 1B, Table 1, $\mathrm{p}<0.0001$ for both). Multiple planned comparisons revealed that when $T$. brunnea exhibited a difference in consumption between high and low species, those preferences were in the same direction as for as Strongylocentrotus purpuratus; both herbivores consumed more of the lower intertidal Microcladia coulteri than its higher 

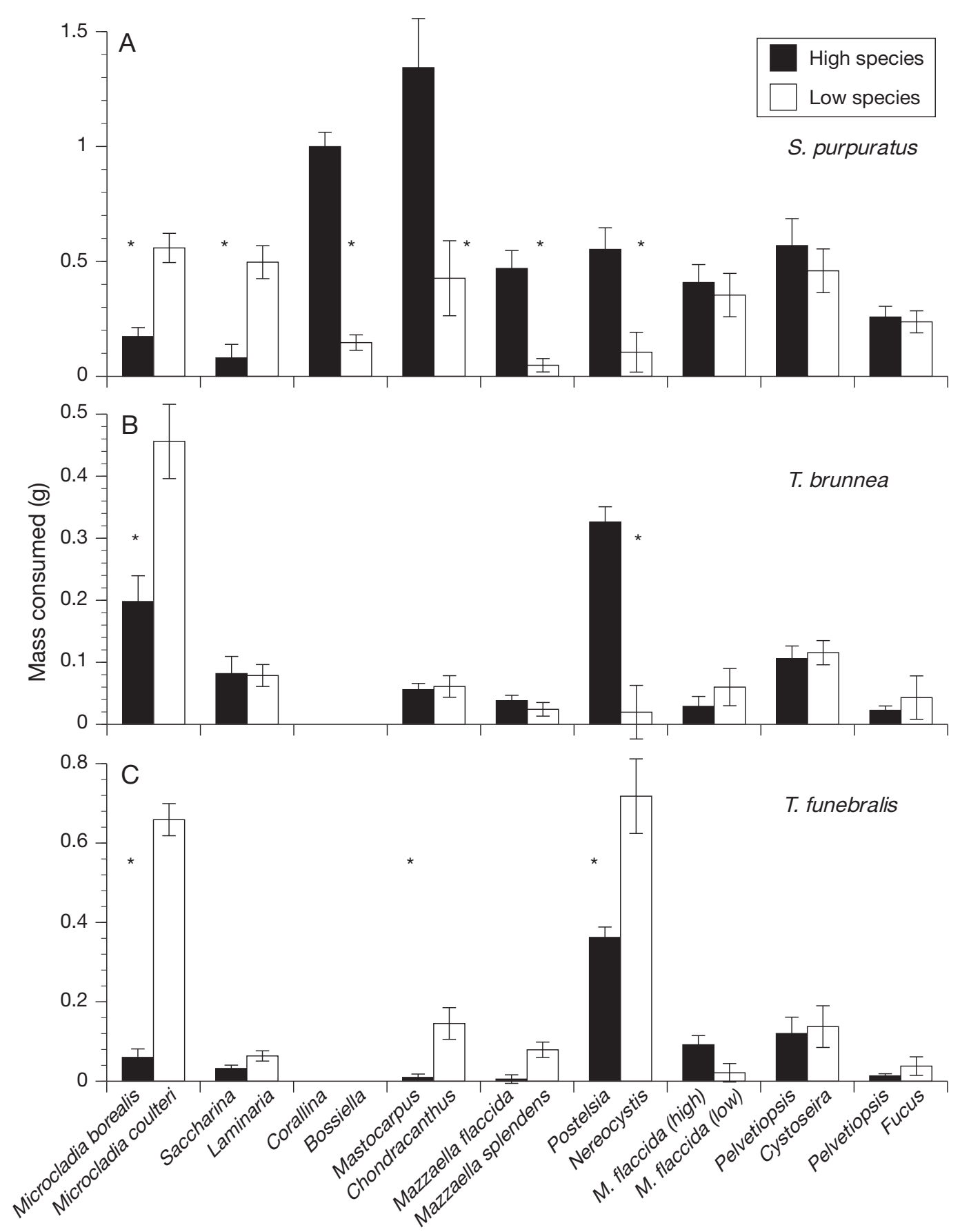

Fig. 1. Paired-choice laboratory feeding assays with live, whole macroalgal tissues and the herbivores (A) Strongylocentrotus purpuratus, (B) Tegula brunnea, and (C) T. funebralis. ${ }^{*}$ Significant difference between algal species (p < 0.05), as calculated by Tukey's HSD. All data are mean \pm SE. Black bars: higher intertidal alga; white bars: lower intertidal alga

intertidal counterpart and more of the higher intertidal Postelsia than its lower intertidal counterpart $(\mathrm{p}<0.05$ for each, Fig. 1B). In homogenized tissue assays, T. brunnea exhibited significant preferences among species pairs but only a marginally significant preference for high over low species (Fig. 2B, Table 1, p $<0.0001$ and $p=0.0583$, respectively).

\section{Tegula funebralis feeding preferences}

The high intertidal snail Tegula funebralis consumed 3 times as much of the lower intertidal algal species than their higher intertidal counterparts, with significant differences among species pairs as well (Fig. 1C, Table 1, $\mathrm{p}<0.0001$ for both tidal height and species pairs). Mul- 
Table 1. Nested ANOVA statistical results from all feeding preference assays, sorted by herbivore and experiment type. Significant $p$ values are noted in bold; significant differences ( $p<0.05$, as Tukey's HSD) between high and low species within experiments are noted with an ${ }^{*}$ on Figs. 1 to 3

\begin{tabular}{|c|c|c|c|c|c|c|}
\hline Expt & Herbivore & Factor & df & SS & $F$ & $\mathrm{p}$ \\
\hline \multirow[t]{9}{*}{ Whole-tissue } & \multirow{3}{*}{$\begin{array}{l}\text { Strongylocentrotus } \\
\text { purpuratus }\end{array}$} & Species pair & 8 & 13.275 & 9.5846 & $<0.0001$ \\
\hline & & Tidal height (Species pair) & 9 & 22.631 & 14.5243 & $<0.0001$ \\
\hline & & Error & 336 & 58.172 & & \\
\hline & \multirow[t]{3}{*}{ Tegula brunnea } & Species pair & 7 & 2.454 & 23.1317 & $<0.0001$ \\
\hline & & Tidal height (Species pair) & 8 & 1.506 & 12.4191 & $<0.0001$ \\
\hline & & Error & 230 & 3.486 & & \\
\hline & \multirow[t]{3}{*}{ T. funebralis } & Species pair & 7 & 9.140 & 49.1602 & $<0.0001$ \\
\hline & & Tidal height (Species pair) & 8 & 4.725 & 22.2365 & $<0.0001$ \\
\hline & & Error & 258 & 6.852 & & \\
\hline \multirow[t]{9}{*}{ Freeze-dried } & \multirow[t]{3}{*}{ S. purpuratus } & Species pair & 5 & 2846.554 & 0.4886 & 0.7845 \\
\hline & & Tidal height (Species pair) & 6 & 79565.517 & 11.3802 & $<0.0001$ \\
\hline & & Error & 182 & 212077.52 & & \\
\hline & \multirow[t]{3}{*}{ T. brunnea } & Species pair & 1 & 159.708 & 53.7357 & $<0.0001$ \\
\hline & & Tidal height (Species pair) & 2 & 17.667 & 2.9722 & 0.0583 \\
\hline & & Error & 64 & 190.215 & & \\
\hline & \multirow[t]{3}{*}{ T. funebralis } & Species pair & 3 & 49.772 & 7.1371 & 0.0002 \\
\hline & & Tidal height (Species pair) & 4 & 8.476 & 0.9116 & 0.4591 \\
\hline & & Error & 138 & 320.789 & & \\
\hline \multirow[t]{3}{*}{ Extracts } & \multirow[t]{3}{*}{ S. purpuratus } & Species pair & 7 & 4694.421 & 0.5473 & 0.7980 \\
\hline & & Tidal height (Species pair) & 8 & 13405.146 & 1.3676 & 0.2111 \\
\hline & & Error & 254 & 311209.92 & & \\
\hline
\end{tabular}

tiple planned comparisons revealed that $T$. funebralis exhibited a significant preference for the lower intertidal Laminaria, Chondracanthus, and Nereocystis over their higher intertidal counterparts ( $p<0.05$ for each, Fig. 1C), with a trend in the same direction for the lower Mazzaella flaccida over Mazzaella splendens ( $p=0.21)$; in no case did T. funebralis significantly prefer the higher intertidal member of a species pair. All tidal height feeding preferences disappeared in homogenized tissue assays, although $T$. funebralis exhibited significant preferences among species (Fig. 2C, Table 1, $\mathrm{p}=0.45$ and $\mathrm{p}=0.0002$, respectively). This precluded the need to conduct feeding assays for $T$. funebralis with chemical extracts for any of the algal species pairs.

\section{Tissue characteristics}

There were significant differences in tissue toughness (as measured by our tissue penetrometer) among species pairs and between tissues at different tidal heights, nested within species pairs (Table 2, p < 0.0001 for both). Tukey's HSD revealed significant differences for 5 of the 8 species pairs tested. The lower tissue was 1.5 to 2 times tougher for Laminaria, Microcladia coulteri, and Mazzaella splendens than their higher counterparts, while the higher tissue was 1.2 to 2 times tougher for Mastocarpus and high Mazzaella flaccida than their lower counterparts (Table 3). Significant differences in tissue toughness for both the Mastocarpus and Mazzaella splendens pairs matched herbivore feeding preferences (with Tegula funebralis preferring the less tough Chondracanthus, and Strongylocentrotus purpuratus preferring the less tough Mazzaella flaccida, Table 4).

There were also significant differences in percent organic content among species pairs and between tissues at different tidal heights, nested within species pairs (Table 2, p < 0.0001 for both). Tukey's HSD revealed significant differences for 4 of the 9 species pairs tested; the higher intertidal species (Corallina, Mastocarpus, Postelsia, and Pelvetiopsis) always had a higher organic content than their lower intertidal counterparts (Table 3). Tissue organic content ranged from a low of $17.23 \%$ for the coralline alga Bossiella to a high of $78.64 \%$ for the foliose red alga Mastocarpus. Significantly higher organic content matched herbivore feeding preferences for Corallina, Mastocarpus, and Postelsia (by Strongylocentrotus purpuratus) as well as for Postelsia (by Tegula brunnea; Table 4).

\section{DISCUSSION}

We found support for an overall trend of the higher intertidal macroalgal species being significantly more 

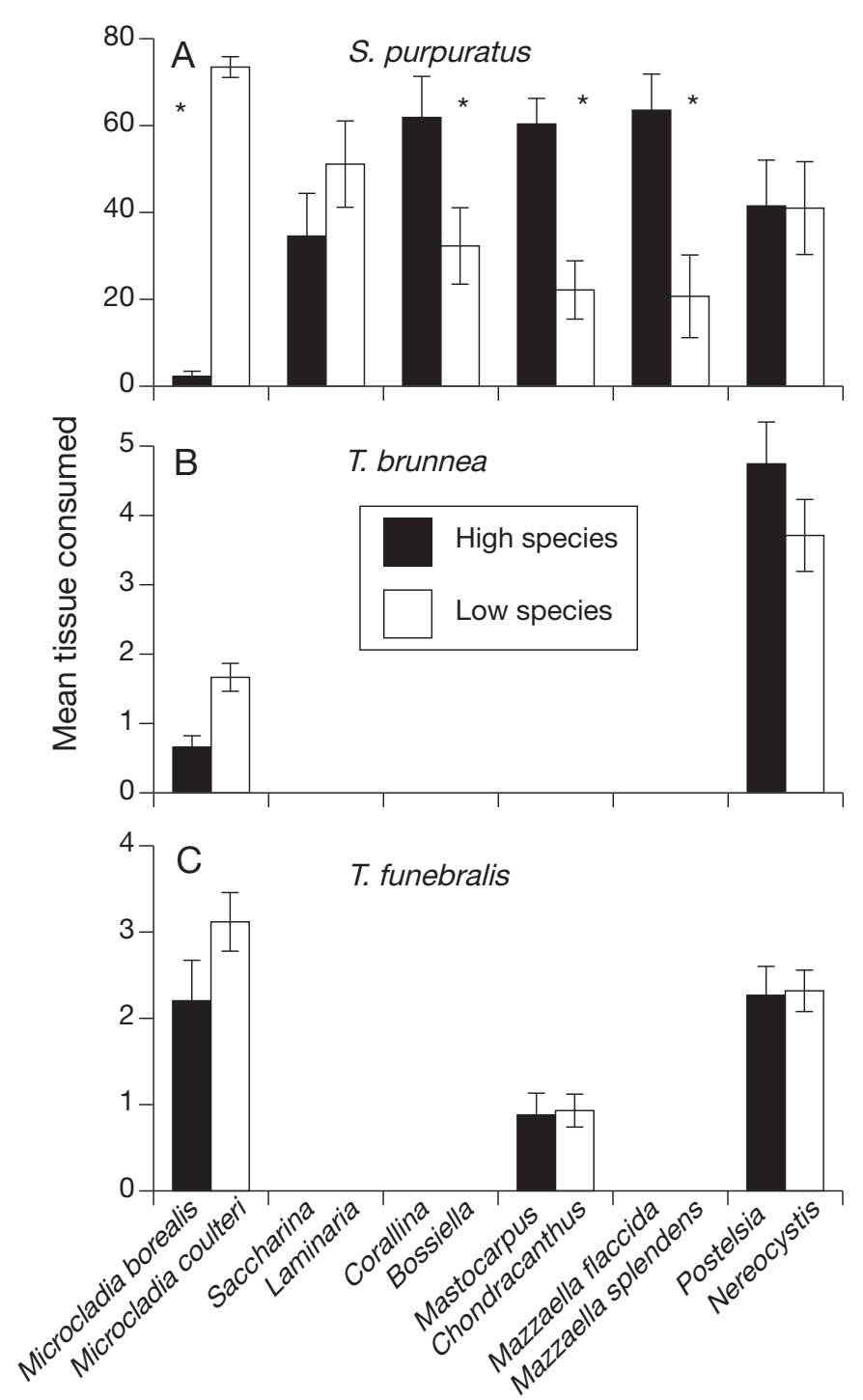

Fig. 2. Paired-choice laboratory feeding assays with freezedried, homogenized macroalgal tissues and the herbivores (A) Strongylocentrotus purpuratus, (B) Tegula brunnea, and (C) T. funebralis. Blank spaces indicate that no feeding assays were performed for a particular herbivore/pair of macroalgal species comparison, due to the lack of a significant feeding preference for live tissue (see Fig. 1). ${ }^{*}$ Significant difference between tissue types ( $\mathrm{p}<0.05)$, as calculated by Tukey's HSD. All data are mean \pm SE. Black bars: higher intertidal alga; white bars: lower intertidal alga. Due to differences in herbivore feeding strategies, the $y$-axis represents the number of squares of window screening consumed by $S$. purpuratus and the $\mathrm{cm}^{2}$ area consumed by Tegula species (see 'Materials and methods')

palatable for 2 of the 3 herbivore species tested (Strongylocentrotus purpuratus and Tegula brunnea but not T. funebralis; Table 1). However, these preferences were not universal across all macroalgal species pairs and, in particular, the overall significant preference for higher macroalgae in T. brunnea appears to
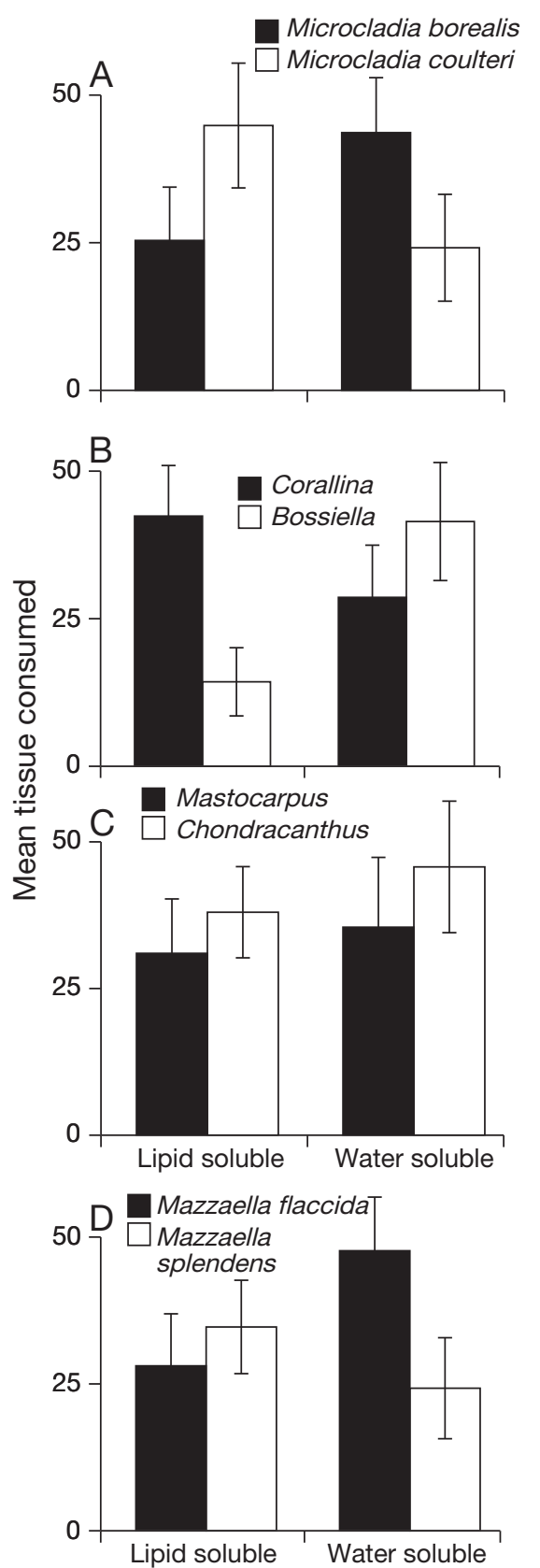

Fig. 3. Paired-choice laboratory feeding assays with macroalgal chemical extracts coated onto Macrocystis homogenized tissues and the herbivore Strongylocentrotus purpuratus. Extracts were divided into lipid-soluble and water-soluble fractions. No extract feeding assays yielded a significant difference between tissue types ( $p<0.05)$, as measured by Tukey's HSD. All data are mean \pm SE. Black bars: higher intertidal alga; white bars: lower intertidal alga. The $y$-axis represents the number of squares of window screening consumed by Strongylocentrotus purpuratus

be driven by a strong preference within only 1 species pair (Postelsia over Nereocystis; Fig. 1B). Unlike elevational gradients for plants in terrestrial systems, in which both herbivory and plant chemical defenses 
Table 2. Nested ANOVA statistical results for both tissue toughness and percent organic content for all macroalgal species pairs. Significant $\mathrm{p}$ values $(\mathrm{p}<0.05)$ are noted in bold

\begin{tabular}{|llrrrr|}
\hline Expt & Factor & df & SS & F & p \\
\hline Tissue toughness & Species pair & 7 & 36330.134 & 29.6042 & $<\mathbf{0 . 0 0 0 1}$ \\
& Tidal height (Species pair) & 8 & 10281.763 & 7.3310 & \\
\% Organics & Error & 64 & 112220.058 & & \\
& Species pair & 8 & 47848.122 & 709.4774 & $<0.0001$ \\
& Tidal height (Species pair) & 9 & 2474.206 & 32.6105 & $<\mathbf{0 . 0 0 0 1}$ \\
& Error & 148 & 1247.665 & & \\
\hline
\end{tabular}

Table 3. Means and SE for tissue toughness and percent organic content of all species pairs. * Significant differences $(p<0.05)$ between high and low species (as Tukey's HSD). N/a indicates that the toughness of the calcified coralline algal pair Corallina and Bossiella exceeded our tissue toughness measurement capabilities

\begin{tabular}{|lccccc|}
\hline \multirow{2}{*}{ Species pair } & Tissue & \multicolumn{2}{c}{ Toughness } & \multicolumn{2}{c|}{ \% Organics } \\
& height & Mean & SE & Mean & SE \\
\hline Microcladia borealis & High & $39.88^{*}$ & 2.93 & 74.55 & 0.97 \\
Microcladia coulteri & Low & 63.80 & 6.43 & 75.75 & 0.88 \\
Saccharina & High & $40.56^{*}$ & 2.91 & 63.06 & 0.91 \\
Laminaria & Low & 84.92 & 8.67 & 63.65 & 1.58 \\
Corallina & High & n/a & & $23.01^{*}$ & 0.77 \\
Bossiella & Low & & & 17.23 & 0.83 \\
Mastocarpus & High & $33.04^{*}$ & 1.87 & $78.64^{*}$ & 0.30 \\
Chondracanthus & Low & 15.92 & 1.37 & 68.42 & 0.87 \\
Mazzaella flaccida & High & $49.76^{*}$ & 6.27 & 74.82 & 0.91 \\
Mazzaella splendens & Low & 77.60 & 16.3 & 73.33 & 0.48 \\
Postelsia & High & 22.92 & 1.89 & $66.98^{*}$ & 0.76 \\
Nereocystis & Low & 19.16 & 2.11 & 50.55 & 1.36 \\
Mazzaella flaccida high & High & $100.20^{*}$ & 7.33 & 71.48 & 0.20 \\
Mazzaella flaccida low & Low & 80.32 & 5.95 & 72.36 & 0.22 \\
Pelvetiopsis & High & 44.43 & 2.62 & $72.92^{*}$ & 0.48 \\
Cystoseira & Low & 40.20 & 3.08 & 61.81 & 0.96 \\
Pelvetiopsis & High & 44.37 & 1.47 & 72.81 & 0.58 \\
Fucus & Low & 35.16 & 0.85 & 73.06 & 0.19 \\
& & & & & \\
\hline
\end{tabular}

in each case, we must examine each herbivore/algal species pair interaction individually, through several types of feeding assays and tissue analyses (Table 4). Strongylocentrotus purpuratus significantly preferred the low intertidal species in 2 pairs and the high intertidal species in 4 (Fig. 1A, Table 4); these differences could be explained by morphology alone for one of the low species (Saccharina) and by both morphology and organic content for one of the high species (Postelsia). In the other 4 cases, the differences may be due to chemical defenses (Microcladia coulteri), chemical defenses and a lower tissue toughness (Mazzaella flaccida), or chemical defenses and a higher organic content (Corallina and Mastocarpus).

Our chemical extract assays indicated that neither lipid nor water soluble extracts alone contained chemicals that altered palatability (Fig. 3, Table 1). However, given that feeding preferences were still present after morphological differences were removed (Fig. 2A), some difference in tissue chemistry may likely explain the feeding preferences of Stron-

generally decrease with increasing elevation (Bruelheide \& Scheidel 1999, Salmore \& Hunter 2001, Alonso et al. 2005), macroalgal palatability in Pacific rocky intertidal systems depends strongly on the particular herbivore under consideration and not only on elevational predictions derived from plant defense theory. These results lead us to urge caution in using the rocky intertidal as an experimentally tractable model system for examining mechanisms underlying biogeographic patterns in herbivore defenses across larger-scale gradients.

The differences in herbivore preference were spread across different algal taxonomic groups (red and brown macroalgae) and functional forms (blades, turfs). To obtain a more detailed understanding of the mechanisms potentially responsible for herbivore selectivity gylocentrotus purpuratus. It may be that volatile chemicals were lost during the extraction process, that a combination of both lipid and water soluble extracts were necessary to influence feeding preferences, or that a combination of morphological and physical factors together may determine algal palatability (Paul et al. 2001). Many macroalgae, including several of the species used here, do produce various water- and lipid-soluble metabolites as defenses against herbivores (Paul et al. 2001, Van Alstyne et al. 2001, Wright et al. 2004, Thornber et al. 2006). Our results do not contradict these findings but merely demonstrate that inter-species variation in chemical defenses does not appear to be important in determining the relative consumption rates among the species in the pairs that we used. 
Table 4. Results of each herbivore/algal species pair interaction where significant preferences occurred, with an indication of the factor(s) that may be responsible for herbivore selectivity. Herbivore names are abbreviated (S.p. = Strongylocentrotus purpuratus; $T . b .=$ T. brunnea; T.f. $=$ T. funebralis). In each pairing, the higher intertidal alga is always listed first. Y means that a specific factor explained the observed preference in live tissue, whereas $\mathrm{N}$ means it did not. A '?' after the Y means that there may have been chemical differences that our results did not detect (see 'Materials and methods') in either the lipid-soluble or watersoluble fraction. See 'n/a' explanation in Table 3

\begin{tabular}{|c|c|c|c|c|c|}
\hline Species pair & $\begin{array}{l}\text { Preferred } \\
\text { alga }\end{array}$ & $\begin{array}{l}\text { Tissue } \\
\text { toughness }\end{array}$ & $\%$ Organics & $\begin{array}{l}\text { Morphological } \\
\text { defense }\end{array}$ & $\begin{array}{l}\text { Chemical } \\
\text { defense }\end{array}$ \\
\hline $\begin{array}{l}\text { Microcladia borealis } \\
\text { Microcladia coulteri }\end{array}$ & Low - all & $\mathrm{N}-$ all & $\mathrm{N}-$ all & $\mathrm{Y}-$ T.b., T.f. & Y (lipid)? - S.p. \\
\hline $\begin{array}{l}\text { Saccharina } \\
\text { Laminaria }\end{array}$ & Low - S.p. & $\mathrm{N}-S \cdot p$ & $\mathrm{~N}-S \cdot p$ & $\mathrm{Y}-S \cdot p$ & N-S.p. \\
\hline $\begin{array}{l}\text { Corallina } \\
\text { Bossiella }\end{array}$ & High - S.p. & $\mathrm{n} / \mathrm{a}$ & $\mathrm{Y}-S \cdot p$ & N-S.p. & Y (lipid)? - S.p. \\
\hline $\begin{array}{l}\text { Mastocarpus } \\
\text { Chondracanthus }\end{array}$ & $\begin{array}{l}\text { High }- \text { S.p. } \\
\text { Low - T.f. }\end{array}$ & $\mathrm{Y}-$ T.f. & $\mathrm{Y}-S \cdot p$ & $\mathrm{Y}-$ T.f. & $\mathrm{Y} ?-$ S.p. \\
\hline $\begin{array}{l}\text { Mazzaella flaccida } \\
\text { Mazzaella splendens }\end{array}$ & High - S.p. & $\mathrm{Y}-S \cdot p$ & $\mathrm{~N}-S \cdot p$ & N-S.p. & $\mathrm{Y}($ water)? - S.p. \\
\hline $\begin{array}{l}\text { Postelsia } \\
\text { Nereocystis }\end{array}$ & $\begin{array}{l}\text { High }- \text { S.p. } \\
\text { High }- \text { T.b. } \\
\text { Low - T.f. }\end{array}$ & $\mathrm{N}-$ all & $\begin{array}{l}\mathrm{Y}-S . p ., \\
T . b .\end{array}$ & $\begin{array}{l}\mathrm{Y}-\text { S.p., } \\
\text { T.b., T.f. }\end{array}$ & $\mathrm{N}-$ all \\
\hline
\end{tabular}

By contrast, our data suggest that chemical defenses did not play a role in the feeding preferences of either Tegula species (Fig. 2). Feeding preferences in $T$. brunnea can be explained by differences in morphology alone (for Microcladia coulteri), and a combination of morphology and organic content (Postelsia). Feeding preferences in $T$. funebralis were driven by differences in morphology alone (for both Microcladia coulteri and Nereocystis), and a combination of morphology and tissue toughness (for Chondracanthus). Interestingly, all morphological differences appeared unrelated to differences in tissue toughness as measured by our penetrometer (Tables 2 to 4), except for $T$. funebralis' preference for Chondracanthus. This suggests that the herbivores base their grazing preferences on other morphological characteristics, such as tissue surface texture, that may be subtle enough to be unobvious to human researchers, or that penetrometers may not provide an accurate assessment of herbivore grazing mechanisms. Algal morphology has been shown to affect feeding preferences of similar Tegula species in California (Schmitt 1996) as well as many other herbivores in other regions (Littler \& Littler 1980, Dethier 1981, Hay et al. 1994).

We designed our algal pairings to minimize morphological and evolutionary differences within each pair as much as possible, given the suite of species that live in rocky intertidal systems on this coastline; it is possible that other pairings may lead to different results. However, preliminary assays that offered urchins or snails a simultaneous choice among 4 of the most common low (Endocladia muricata, Fucus,
Mastocarpus, Pelvetiopsis) and 4 most common high intertidal macroalgae (Chondracanthus, Gastroclonium subarticulatum, Mazzaella splendens, Prionitis lyallii) also failed to find consistent support for a greater palatability of higher intertidal species (C. Thornber unpubl. data).

Macroalgae may also exhibit significant intraspecific differences in palatability (Wright et al. 2000, Van Alstyne et al. 2001). For example, both the morphological and chemical defenses of at least one of the intertidal algae used here (Mazzaella flaccida) can vary with life-history stage and reproductive status (Thornber et al. 2006). We restricted our experiments to comparing only vegetative, non-reproductive tissues to standardize across all species. It is possible that reproductive tissues of the same species we examined could potentially differ in palatability from their vegetative counterparts and there could be intertidal gradients in the palatability of reproductive individuals that we did not investigate.

In addition, at our site, only one species (Mazzaella flaccida) had a vertical distribution broad enough to allow for robust intraspecific palatability comparisons across tidal heights. While lower intertidal M. flaccida individuals are generally larger and more deeply pigmented than higher intertidal $M$. flaccida individuals (C. Thornber unpubl. data), none of the 3 herbivores exhibited a significant preference between high and low individuals. Thus, determining if there are interspecific (vs. intraspecific) differences in palatability that correspond to relative tidal heights is appropriate for this system. 
One of the most surprising findings of our study was that herbivore preference, when present, was best predicted by the tidal elevation of the alga compared to that of the particular herbivore: higher intertidal grazers typically preferred lower intertidal algae and vice versa. Variation in the effectiveness of particular defenses against different herbivores has been documented for other macroalgal species as well (Hay et al. 1987, Cronin \& Hay 1996). In our context, these differences in palatability could represent an evolutionary response by algae that are specific to frequently encountered herbivores with different feeding modes. In particular, gastropods are dominant high intertidal grazers in our system and they rasp tissue surfaces, and thus may be more affected by changes in surface tissue morphology. In contrast, urchins are dominant subtidal and low intertidal grazers that consume the entire thallus readily; that they are often unaffected by toughness of thalli is evidenced by their habit of consuming crustose coralline algae (Wai \& Williams 2005) and even boring holes into granitic rock (Erickson et al. 2006).

Alternatively, differences in algal susceptibility to different herbivores could be the indirect result of algal adaptation to physical stresses. For example, if high intertidal algae are more often covered with thick cuticles or other anti-desiccation adaptations, then this might indirectly influence the palatability of these algae to surface-rasping herbivores like snails, but not to grazers such as urchins. Thus, if herbivory is important in setting the distributions of some species in our system, then palatable algae should generally grow where their herbivores are not present. The overall preference of Strongylocentrotus purpuratus for tissues from higher intertidal species may serve as a mechanism for excluding these species from the urchins' preferred habitat and setting their lower intertidal range limit, as these urchins are a dominant intertidal herbivore (Paine \& Vadas 1969, Thornber et al. 2006). Similarly, while individual Tegula funebralis consume far less than individual urchins, these snails can reach very high densities in the field (Thornber et al. 2006). Although upper distributional limits to algae are usually determined by physical stresses in our system (Foster 1982, Harley 2003), this need not be the case for all algal species.

In a broader context, recent introductions of plant species into new habitats do suggest that evolutionary history can influence herbivore feeding preferences. In analyses by Parker \& Hay (2005) and Parker et al. (2006), native herbivores were shown to suppress the abundance of exotic plants more than native plants and exotic herbivores suppressed the abundance of native plants more than exotic plants, due to herbi- vore feeding preferences for species with which they do not share an evolutionary history. Our results could be interpreted as offering partial support for this trend, with macroalgae often being most heavily defended against herbivores with which they most commonly co-occur.

Acknowledgements. Thanks to E. Preisser, A. Underwood, and 2 anonymous reviewers for helpful comments. M. Nydam and E. Thomas provided field and laboratory assistance. L. Gonzalez provided statistical help. C.S.T. was supported by the University of Rhode Island, an NIGMS MORE Institutional Research and Academic Career Development Award to UC Davis and SFSU (see http://prof.ucdavis.edu), Grant No. K12GM00679, and the Pt. Reyes National Seashore. This is contribution number 2407 of the Bodega Marine Laboratory.

\section{LITERATURE CITED}

Abbott IA, Hollenberg G (1976) Marine algae of California. Stanford University Press, Stanford, CA

Alonso C (1999) Variation in herbivory by Yponomeuta mahalebella on its only host plant Prunus mahaleb along an elevational gradient. Ecol Entomol 24:371-379

Alonso C, Perez R, Nieto P, Delgado J (2005) Gender dimorphism and altitudinal variation of secondary compounds in leaves of the gynodioecious shrub Daphne laureola. J Chem Ecol 31:139-150

$>$ Bolser RC, Hay ME (1996) Are tropical plants better defended? Palatability and defenses of temperate vs. tropical seaweeds. Ecology 77:2269-2286

Bruelheide H, Scheidel U (1999) Slug herbivory as a limiting factor for the geographical range of Arnica montana. J Ecol 87:839-848

Byrnes J, Stachowicz JJ, Hultgren KM, Hughes AR, Olyarnik SV, Thornber CS (2006) Predator diversity strengthens trophic cascades in kelp forests by modifying herbivore behaviour. Ecol Lett 9:61-71

Carlton JT (ed) (2007) The Light and Smith manual: intertidal invertebrates from Central California to Oregon. University of California Press, Berkeley, CA

> Carpenter RC (1986) Partitioning herbivory and its effects on coral reef algal communities. Ecol Monogr 56:345-364

> Chavanich S, Wilson KA (2000) Rocky intertidal zonation of gammaridean amphipods in Long Island Sound, Connecticut. Crustaceana 73:835-846

Connell JH (1961) The influence of interspecific competition and other factors on the distribution of the barnacle Chthamalus stellatus. Ecology 42:710-723

Cronin G, Hay ME (1996) Susceptibility to herbivores depends on recent history of both the plant and animal. Ecology 77:1531-1543

Deal MS (1997) The causes and consequences of within-species variation in seaweed chemical defenses. University of North Carolina, Chapel Hill, NC

Dethier MN (1981) Heteromorphic algal life histories: the seasonal pattern and response to herbivory of the brown crust Ralfsia californica. Oecologia 49:333-339

> Duffy JE, Hay ME (1991) Food and shelter as determinants of food choice by an herbivorous marine amphipod. Ecology 72:1286-1298

Erickson AA, Paul VJ, Van Alstyne KL, Kwiatkowski LM (2006) Palatability of macroalgae that use different types of chemical defenses. J Chem Ecol 32:1883-1895 
Floeter SR, Behrens MD, Ferreira CEL, Paddack MJ, Horn $\mathrm{MH}$ (2005) Geographical gradients of marine herbivorous fishes: patterns and processes. Mar Biol 147:1435-1447

Foster MS (1982) Factors controlling the intertidal zonation of Iridaea flaccida (Rhodophyta). J Phycol 18:285-294

Foster MS, Nigg EW, Kiguchi LM, Hardin DD, Pearse JS (2003) Temporal variation and succession in an algal dominated high intertidal assemblage. J Exp Mar Biol Ecol 289:15-39

Gaines SD, Lubchenco J (1982) A unified approach to marine plant-herbivore interactions. II. Biogeography. Annu Rev Ecol Syst 13:111-138

Granado I, Caballero P (2001) Feeding rates of Littorina striata and Osilinus atratus in relation to nutritional quality and chemical defenses of seaweeds. Mar Biol 138: $1213-1224$

Harley CDG (2003) Abiotic stress and herbivory interact to set range limits across a two-dimensional stress gradient. Ecology 84:1477-1488

Hay ME, Steinberg PD (1992) The chemical ecology of plantherbivore interactions in marine versus terrestrial communities. In: Rosenthal GA, Berenbaum MR (eds) Herbivores: their interactions with secondary plant metabolites, 2E, Vol II: Evolutionary and ecological processes. Academic Press, Burlington, MA, p 371-413

Hay ME, Duffy JE, Pfister CA, Fenical W (1987) Chemical defense against different marine herbivores: Are amphipods insect equivalents? Ecology 68:1567-1580

Hay ME, Paul VJ, Lewis SM, Gustafson K, Tucker J, Trindell RN (1988) Can tropical seaweeds reduce herbivory by growing at night? Diel patterns of growth, nitrogen content, herbivory, and chemical versus morphological defenses. Oecologia 75:233-245

Hay ME, Kappel QE, Fenical W (1994) Synergisms in plant defenses against herbivores: interactions of chemistry, calcification, and plant quality. Ecology 75:1714-1726

> Hines AH (1982) Coexistence in a kelp forest: size, population dynamics, and resource partitioning in a guild of spider crabs (Brachyura, Majidae). Ecol Monogr 52:179-198

Horn MH, Murray SN, Edwards TW (1982) Dietary selectivity in the field and food preferences in the laboratory for two herbivorous fishes (Cebidichthys violaceus and Xiphister mucosus) from a temperate intertidal zone. Mar Biol 67: $237-246$

Lane CE, Mayes C, Druehl LD, Saunders GW (2006) A multigene molecular investigation of the kelp (Laminariales, Phaeophyceae) supports substantial taxonomic re-organization. J Phycol 42:493-512

Levin D (1976) Alkaloid-bearing plants. An ecogeographic perspective. Am Nat 110:261-284

Littler MM, Littler DS (1980) The evolution of thallus form and survival strategies in benthic marine macroalgae: field and laboratory tests of a functional form model. Am Nat 116:25-44

Long JD, Trussell GC (2007) Geographic variation in seaweed induced responses to herbivory. Mar Ecol Prog Ser 333: 75-80

Menge BA (1991) Relative importance of recruitment and other causes of variation in rocky intertidal community structure. J Exp Mar Biol Ecol 146:69-100

Menge BA, Sutherland JP (1976) Species diversity gradients: synthesis of the roles of predation, competition, and temporal heterogeneity. Am Nat 110:351-369

> Menge BA, Sutherland JP (1987) Community regulation: variation in disturbance, competition, and predation in relation to environmental stress and recruitment. Am Nat 130:730-757
Meyer KD, Paul VJ (1995) Variation in aragonite and secondary metabolite concentrations in the tropical green seaweed Neomeris annulata: effects on herbivory by fishes. Mar Biol 122:537-545

Morris RH, Abbott DP, Haderlie EC (1980) Intertidal invertebrates of California. Stanford University Press, Stanford, CA

Murray SN (1989) Variations in standing stocks of central California macrophytes from a rocky intertidal habitat before and during the 1982-83 El Niño. Mar Ecol Prog Ser 58:113-122

Murray SN, Horn MH (1989) Seasonal dynamics of macrophyte populations from an eastern north Pacific rockyintertidal habitat. Bot Mar 32:457-473

Paine RT, Vadas RL (1969) The effects of grazing by sea urchins, Strongylocentrotus spp., on benthic algal populations. Limnol Oceanogr 14:710-719

Paine RT, Castilla JC, Cantino J (1985) Perturbation and recovery patterns of starfish-dominated intertidal assemblages in Chile, New Zealand, and Washington State. Am Nat 125:679-691

> Parker JD, Hay ME (2005) Biotic resistance to plant invasions? Native herbivores prefer non-native plants. Ecol Lett 8:959-967

> Parker JD, Burkepile DE, Hay ME (2006) Opposing effects of native and exotic herbivores on plant invasions. Science 311:1459-1461

Paul VJ, Cruz-Rivera E, Thacker RW (2001) Chemical mediation of macroalgal-herbivore interactions: ecological and evolutionary perspectives. In: McClintock JB, Baker BJ (eds) Marine chemical ecology. CRC Press, Boca Raton, FL, p 227-265

Pennings SC, Silliman BR (2005) Linking biogeography and community ecology: latitudinal variation in plant-herbivore interaction strength. Ecology 86:2310-2319

Pennings SC, Zimmer M, Dias N, Sprung M and others (2007) Latitudinal variation in plant-herbivore interactions in European salt marshes. Oikos 116:543-549

Rhoades DF (1979) Evolution of plant chemical defense against herbivores. In: Rosenthal GA, Janzen DH (eds) Herbivores: their interaction with secondary plant metabolites. Academic Press, New York, p 1-55

Salmore AK, Hunter MD (2001) Elevational trends in defense chemistry, vegetation, and reproduction in Sanguinaria canadensis. J Chem Ecol 27:1713-1727

Scheibling RE (1994) Molluscan grazing and macroalgal zonation on a rocky intertidal platform at Perth, Western Australia. Aust J Ecol 19:141-149

Scheidel U, Rohl S, Bruelheide H (2003) Latitudinal gradients of generalist and specialist herbivory on three montane Asteraceae. Acta Oecol Int J Ecol 24:275-283

Schiel DR, Steinbeck JR, Foster MS (2004) Ten years of induced ocean warming causes comprehensive changes in marine benthic communities. Ecology 85:1833-1839

Schmitt RJ (1996) Exploitation competition in mobile grazers: trade-offs in use of a limited resource. Ecology 77:408-425

> Snellen CL, Hodum PJ, Fernandez-Juricic E (2007) Assessing western gull predation on purple sea urchins in the rocky intertidal using optimal foraging theory. Can J Zool 85: 221-231

> Sousa WP, Schroeter SC, Gaines SD (1981) Latitudinal variation in intertidal algal community structure: the influence of grazing and vegetative propagation. Oecologia 48: 297-307

Steinberg PD (1985) Feeding preferences of Tegula funebralis and chemical defenses of marine brown algae. Ecol Monogr 55:333-350 
Thornber CS, Stachowicz JJ, Gaines SD (2006) Tissue type matters: selective herbivory on different life history stages of an isomorphic alga. Ecology 87:2255-2263

> Van Alstyne KL, Whitman SL, Ehlig JM (2001) Differences in herbivore preferences, phlorotannin production, and nutritional quality between juvenile and adult tissues from marine brown algae. Mar Biol 139:201-210

Wai TC, Williams GA (2005) The relative importance of herbivore-induced effects on productivity of crustose coralline algae: sea urchin grazing and nitrogen excretion. J Exp Mar Biol Ecol 324:141-156

Editorial responsibility: Antony Underwood, Sydney, New South Wales, Australia
Wolcott TG (1973) Physiological ecology and intertidal zonation in limpets (Acmaea): a critical look at limiting factors. Biol Bull 145:389-422

Wright JT, De Nys R, Steinberg PD (2000) Geographic variation in halogenated furanones from the red alga Delisea pulchra and associated herbivores and epiphytes. Mar Ecol Prog Ser 207:227-241

Wright JT, De Nys R, Poore AGB, Steinberg PD (2004) Chemical defense in a marine alga: heritability and the potential for selection by herbivores. Ecology 85: 2946-2959

Submitted: February 16, 2007; Accepted: January 7, 2008 Proofs received from author(s): June 27, 2008 